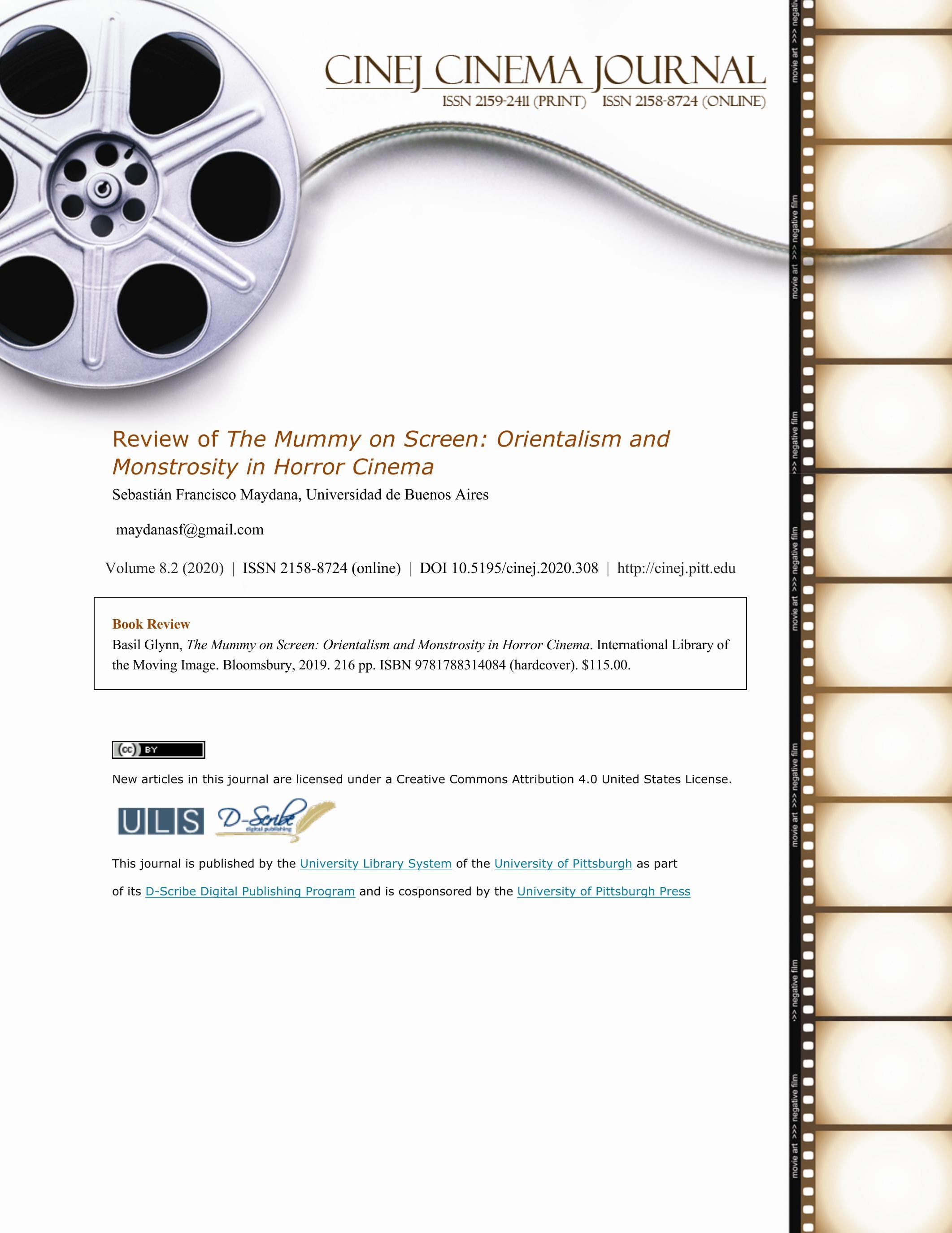




\section{Review of The Mummy on Screen: Orientalism and Monstrosity in Horror Cinema Sebastián Francisco Maydana}

Only six horror films have ever been nominated for an Oscar award. Only one of them has

won 'best picture', and none (unless we were to count Spielberg's monstrous shark as such) were

'monster movies'. In fact, film monsters are far from praised among critics, and perhaps the least

appreciated of them is the Mummy. When Dr Basil Glynn set out to write this book, he began by

acknowledging this fact, pointing out that the Mummy "has forever remained an Outsider, a

monstrous manqué, an 'Other' among the great monstrous 'Others' of the cinema”. In other words,

the bandaged brute is presented to us as the ultimate underdog, and few things are more effective

in making the reader turn the page that the prospect of watching the underdog win in the end. The

promise, in this case, is that all these critics, scholars and cultural commentators who neglected

the Mummy as a minor monster are dead wrong, and that their arguments can and will be

dismantled one by one.

Based on this premise alone, Basil Glynn's The Mummy on Screen is guaranteed to hold the interest of casual readers and horror film connoisseurs alike. It is in a way the definitive Mummy book, as it seems to have an opinion on each of the main discussions that surround the 
Mummy genre, and an informed one at that. Not only it presents original and illuminating research on the topic, but the main theses of the book are condensed in neat and simple phrases.

It should be clarified that this book does not intend to be a historical account or a factual essay on Egyptian mummies, and while it would have certainly benefited from the ample available bibliography on the topic, this does not diminish its merits. However, I would not be much of an Egyptologist were I not to point out a series of historical inaccuracies that spoil an otherwise impeccable work. For instance, Glynn discusses André Bazin's famous 'Mummy complex' regarding photography and cinema. Following the French scholar, he claims that "film, like mummification, preserves human beings practically forever. Unlike mummification, it can animate them". As it happens, ancient Egyptian mummies did take part in social life just as if they were alive, and were periodically brought out of the tomb to participate in rituals such as the 'opening of the mouth', so they had both animacy and agency. Furthermore, when discussing the possible influence of Howard Carter's discovery of Tutankhamun's tomb in 1922, Glynn comments that such event was mainly a publicity show, and that the discovery itself did not provide useful information for Egyptologists given that Tutankhamun was a "minor Pharaoh". This is certainly false, and we now know that during his short reign Tutankhamun was among other things responsible for restoring the cult of Amun and Ptah, moving the capital to Thebes, building a number of perdurable monuments and waging war against the enemies of the kingdom. 
But it would be unfair to judge the book by its Egyptological misinformation, as it is made clear throughout it that the Egyptian mummy has nothing to do with the capitalised Mummy, a creature concocted in the West by Westerners. As such, the amount of information and insight it can dispense about our own society greatly surpasses what little it can teach about history, Egyptian or otherwise.

The origins of this construction are discussed in great depth, and the reader is provided with a good understanding of what mummies were to European and American society through the past centuries. The main tool that Glynn uses to analyse the reception of mummies in Europe is Edward Said's now classic book Orientalism (1978). Said famously describes how the East is constructed as a mirror image of European society, focusing on the exaggeration of differences to the point that the actual East was very different from the fictional Orient. It is a convenient starting point for analysis, but it needs (in my opinion) to be discussed further. No such discussion is found in Glynn's book, and the notion of Orientalism fits like a glove in his account of mummies in the West. Especially as he tries to define what a Mummy film entails, not only as a form of delimiting the object of its study, but also as a tool for further analysis.

One fascinating fact about mummies is the fascination they awakened in the West, namely Europe and the USA. A delightfully detailed account of Victorian unwrapping and exhibition of Egyptian mummies is provided in the book, but it lacks the counterpart, when Victorians visited 
Egypt to view the mummies and its pits, for which I would recommend reading William Wilde's

(Oscar's father) diary of his explorations. Mummies, when taken out of context, become commoditised, a product subject to being sold, bought and consumed either as fertiliser, a miracle cure, as a substitute for firewood, and of course, as an object of public and private spectacle. In short, "for centuries the Mummy was not human but instead a commercial artefact".

The second part of the book is devoted to mummies on literature and silent films. While he does recall the earliest occurrences of mummy stories dating to the 16th century, it is only in the 19th century that they become human again. There is a rediscovery of all things Egyptian (this is the golden era of Orientalism), mummies included, and they begin to populate the literature. A genealogy of the mummy genre is neatly laid out, encompassing such names as Arthur Conan Doyle, Mary Shelley, Bram Stoker and Edgar Allan Poe.

Another strong point of the book is the way it recovers a lesser-known part of the Mummy films history: the silent cinema years. Glynn reviews over fifty examples of silent films featuring mummies, many of them complete with their synopses, and he does this while celebrating the diversity of genres: mainly comedy and romance, but also horror.

Only in the second half of the book does he analyse The Mummy (1932), the obvious starting point of many a work on the Mummy genre. Here, it is but one of the many incarnations of the Mummy on screen, and while he goes in great depth in the description of this film and its 
interpretations, this is only due to it having the largest amount of discussion on the field, not because he thinks it is the 'archetypal' mummy film. The opposite is in fact true, as taken within the corpus of mummy films as a whole, it is somewhat an exception.

Whether the 1930s Mummy is the 'iconic' Mummy or not is indistinct. What is shown here is the fact that the Mummy is a construct that is enriched over the years and with every film appearance. So, 1940s Universal Mummy films are redeemed after being unjustly mistreated by critics and scholars. Glynn proves sufficiently that they held a great deal of importance in developing the Mummy's story and even setting the main physical features of the 'classic' Mummy. The tendency in these years to seriation, seen all too often as a sign of financial ambition, is in this book portrayed in terms of a perfect opportunity to develop the monster's character traits. It is also revealed that the extent of these films influence over future works has been criminally undermined, as they were the first films to develop (decades before it became popular) many plot points that make up the slasher genre and even zombie films.

Hammer films' Mummy of the 1950s is also redeemed, not just out of subjective taste, but in order to point out their objective importance for the genre. Valued for what they are instead of for what critics wrote about them, the merits of each film start to emerge. While the 1940s brought an aesthetics and a backstory to the Mummy's enduring lore, Hammer's Mummy poses profound moral questions. It is precisely here that Glynn makes the historical assumptions he carefully 
avoided in the previous chapters. Historians tend indeed to explain specific cultural occurrences by their larger historical context. But art and literature are hardly passive mirrors of the general course of history, and it is in this understanding that Glynn often opts for a rigid Rosenstonian scepticism. However, I was saying, he does convincingly link Hammer's Mummy to the last dying breaths of British colonialism following the Suez fiasco in ' 56.

Elegantly written, with a gift for puns, word-play and serious words too, The Mummy on Screen shows that if we manage to see past the bandages, the Mummy is a more flexible and multifaceted monster that we have so far believed. In contrast to the precise way in which Glynn condenses his main theses in witty sentences, the Mummy is itself imprecise, and because it defies definitions, it can mutate easily. And so, "the most neglected of all classic cinematic monsters" is finally vindicated.

Sebastián Francisco Maydana

$\mathrm{PhD}$ Candidate in History

Universidad de Buenos Aires, Argentina maydanasf@gmail.com 